\title{
Characteristics of a laccolith along the LRTPB fault zone between Pearl River Mouth Basin and Southwest Taiwan Basin
}

\author{
Boan $\mathrm{Li}^{1,2,3}$, Qunshu Tang ${ }^{1,2, *}$, Pin Yan ${ }^{1,2}$, Junhui $\mathrm{Yu}^{2}$, and Xiao Wang ${ }^{4}$ \\ ${ }^{1}$ Southern Marine Science and Engineering Guangdong Laboratory (Guangzhou), Guangzhou, China \\ ${ }^{2}$ Key Laboratory of Ocean and Marginal Sea Geology, South China Sea Institute of Oceanology, Innovation Academy of South \\ China Sea Ecology and Environmental Engineering, Chinese Academy of Sciences, Guangzhou, China \\ ${ }^{3}$ University of Chinese Academy of Sciences, Beijing, China \\ ${ }^{4}$ Hainan Branch Company of CNOOC (China) Ltd., Haikou, China
}

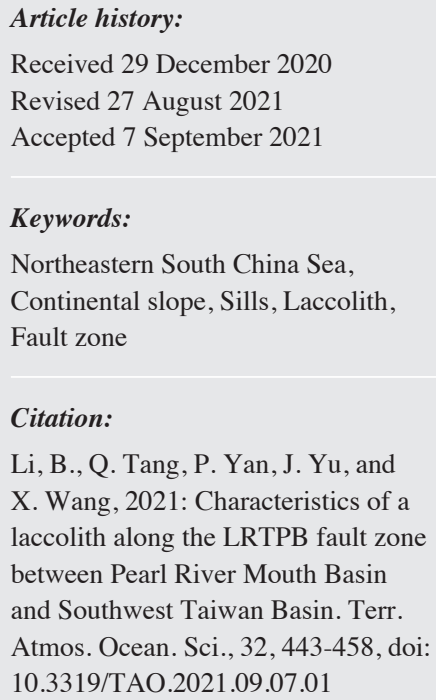

\begin{abstract}
The northern margin of the South China Sea (SCS) is often regarded as a magmapoor passive continental margin. Magmatic activities occurred after the cessation of seafloor spreading were founded mainly over the Continent-Ocean Transition (COT) zone. Intrusive rocks are observed in the Luzon-Ryukyu Transform Plate Boundary (LRTPB) dividing Southwest Taiwan Basin (SWTB) and Pearl River Mouth Basin (PRMB) north of the COT and their evolution mechanisms are not very well-studied. Here, detailed structural and geophysical features of a large-scale anomaly (LSA) is revealed from high-resolution multi-channel seismic (MCS) profiles over the LRTPB dividing the SWTB and the PRMB. After velocity estimation, AVO analysis, and geological interpretation for the LSA, we suggest that the LSA is an intrusive igneous rock and further classified as a laccolith. The coexistence of the laccolith and surrounding sills over the LRTPB shows that the north limit of magmatism is further north than the COT zone. The elongated shape of the laccolith is accordant to the NW directional LRTPB, indicating that magmatic activities of study region maybe controlled by the faulting.
\end{abstract}

\section{INTRODUCTION}

South China Sea is one of the largest marginal seas in the western Pacific. It is surrounded by different types of continental rifted margins: subducting continental margin in the east, pull-apart continental margin in the west, and compressional continental margin in the south (Tapponnier et al. 1982; Leloup et al. 1995; Bautista et al. 2001; Clift et al. 2008). The northern margin of SCS (Fig. 1), recognized as a typical passive continental margin today, has experienced subduction in the late Mesozoic and the subsequent seafloor spreading in the Cenozoic (Taylor and Hayes 1983; Yang and Fang 2015).

According to whether the magmatism is the dominant process in the passive continental margins or not, passive margins are classified as two major types, i.e., magma-rich

\footnotetext{
* Corresponding author

E-mail:tqsh@scsio.ac.cn
}

and magma-poor margins (Geoffroy 2005; Franke 2013). Although there are many seamounts and an extensive lower crustal high-speed layer are identified in the northern margin of the SCS, the northern margin is still considered as the magma-poor margin (Lester et al. 2014; McIntosh et al. 2014; Fan et al. 2017; Song et al. 2017; Li et al. 2019). Previous studies concluded that these seamounts are formed between the late Oligocene to mid-Miocene (Liao et al. 2016; Fan et al. 2017; Song et al. 2017). Spatially, most of the seamounts are located in the south of Dongsha islands or on the continental-ocean transition (COT) zone (Fig. 1b). Exposed volcanic seamounts in the region north of COT are seldom observed. However, lava flows and sills are often observed on seismic profiles from previous studies as shown in Fig. 1 (Yeh and Hsu 2004; Yeh et al. 2012; Lester et al. 2014; Liao et al. 2016). Nevertheless, little attention has been paid to them. This limits a more thorough understanding of magmatism on the region north of COT. Whether the northern 
boundary of the COT is the north limit of the magmatism? What is the evolution mechanism of this magmatism? These questions need to be investigated in detail.

In this study, many magma intrusions are observed from high-resolution seismic profiles on the LRTPB dividing the SWTB and PRMB north of the COT. Among them, an elongated LSA over $15-\mathrm{km}$ long was imaged in two intersecting seismic profiles. The features including spatial scale, velocity property, and AVO characteristics of the LSA are investigated in detail. A magma intrusion mechanism is proposed close to the LRTPB dividing the SWTB and PRMB north of COT.

\section{GEOLOGIC AND TECTONIC BACKGROUND}

The East Asian continent were formed from Permian to Triassic (257 - $205 \mathrm{Ma}$ ). During this time, the northeastern SCS and the continental areas were in the same sedimentary system. During early Jurassic to Cretaceous (181 - $82 \mathrm{Ma}$ ), as the Eurasian plate moves south, the Pacific plate moves west and the Indian Ocean plate moves northeast, the SCS area experienced frequent fault activity and magmatic activity (Uyeda and Miyashiro 1974; Jahn et al. 1976; Zhang 2014; Lüdmann and Wong 1999). After that, the SCS was formed by experiencing successive dominant movements, including Shenhu Movement, Nanhai Movement, and Dongsha Move- ment (83 Ma to present) (Yi et al. 2007; Li et al. 2008).

Among these movements, the Dongsha Movement occurred around the Dongsha area after the SCS seafloor spreading in the Late Cenozoic (Yan et al. 2001). The most evident feature caused by the Dongsha Movement is the occurrence of significant angular unconformities and stratigraphic loss in the strata, accompanied with fracturing and magmatic activities (Chen et al. 2005; Lin et al. 2006; Zhao et al. 2012). After the cessation of seafloor spreading, due to the oceanic and continental lithosphere extension related to cooling and thermal contraction, decompressive melting occurred beneath the continental slope, and large-scale magmatism occurred on the northern margin of the SCS (Zhang et al. 2016; Wan et al. 2017; Liu et al. 2021). The magma reaches to the upper crust and forms sills, dicks and volcanoes (Liu et al. 2021). Mafic basalt is the primary type of these igneous rocks (Yan et al. 2006; Sun et al. 2019). Analysis of seamount samples in the Dongsha region shows that most seamounts are formed by post-spreading magmatism at $<16 \mathrm{Ma}$ (Yan et al. 2006), suggesting that magmatism did not end after seafloor spreading. Previous studies reported numerous volcanic eruptions related to the Dongsha Movement (Lüdmann and Wong 1999; Lüdmann et al. 2001; Yan et al. 2001). Most of these volcanic eruptions occurred along faults between the thinned continental and oceanic crust, thus forming part of the so-called COT (Yan et al. 2006). (a)

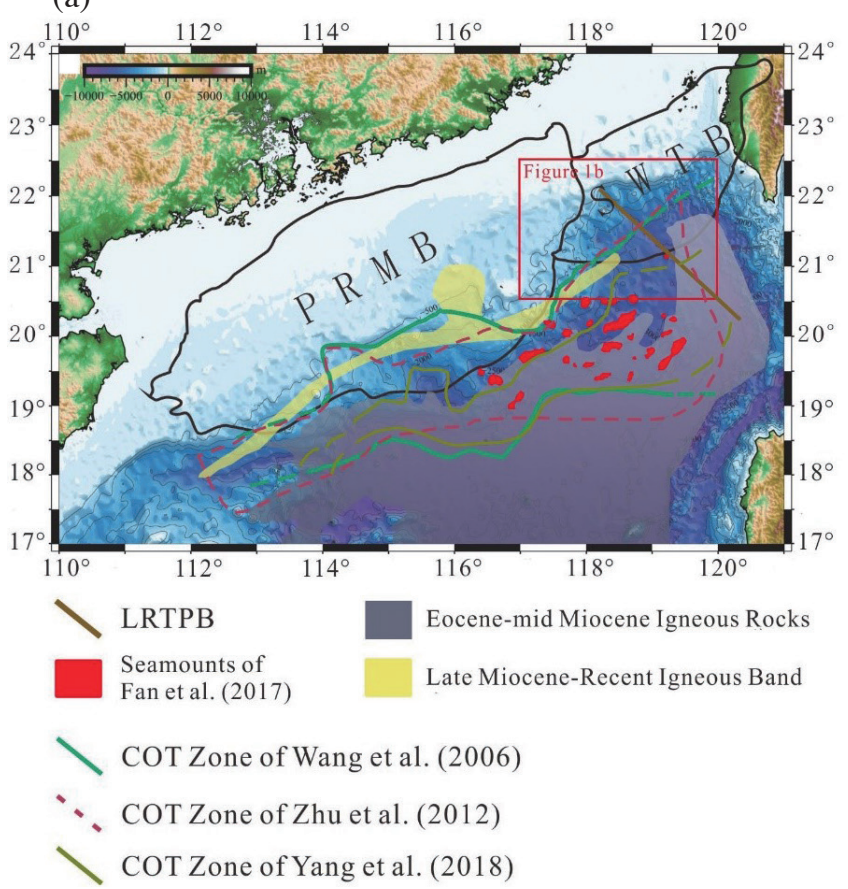

(b)

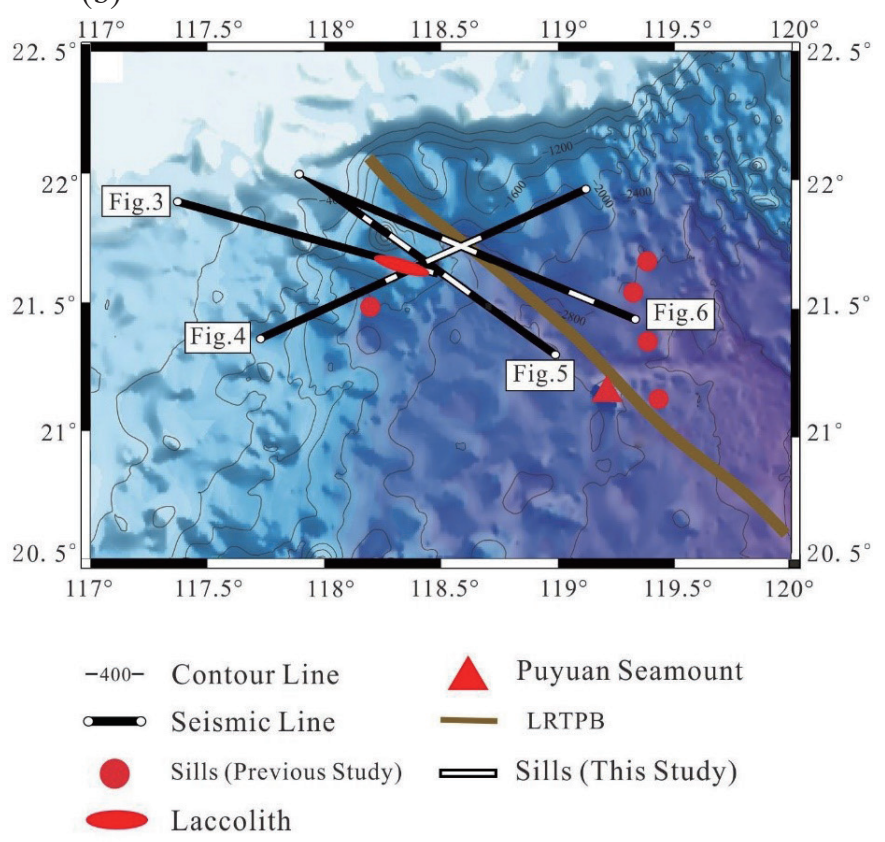

Fig. 1. (a) Regional tectonic map of the northern margin of SCS. PRMB: Pearl River Mouth Basin; SWTB: Southwest Taiwan Basin; COT: Continent-Ocean Transition; LRTPB: Luzon-Ryukyu Transform Plate Boundary. COT, Seamounts, Late Miocene-Recent Igneous Band, Eocene-mid Miocene Igneous Rocks, and LRTPB are modified from (Sibuet et al. 2002; Hsu et al. 2004; Wang et al. 2006; Yan et al. 2006; Zhu et al. 2012; Fan et al. 2017; Yang et al. 2018). (b) Close-up of the LRTPB and survey lines (black) as outlined with red box in (a). Sills of Previous Study are modified from (Yeh et al. 2012; Lester et al. 2014; Liao et al. 2016). 
A NW directional fault zone, named as Luzon-Ryukyu Transform Plate Boundary (LRTPB) goes along the Taiwan Canyon (or Formosa Canyon) and extends southeast to the Manila Trench (Hsu et al. 2004; Yeh and Hsu 2004; Sibuet et al. 2002) (Fig. 1a). The LRTPB probably became inactive at $20 \mathrm{Ma}$ (Hsu et al. 2004). During the post-spreading Miocene volcanism and the Pliocene Dongsha uplift event, the LRTPB was re-activated. Unfortunately, this fault zone always cannot be clearly imaged on seismic profiles (Yeh et al. 2012; Li et al. 2019). However, the two sides of the LRTPB differ significantly in topography and magnetic anomalies, indicating that the fault zone has a significant impact on the tectonic and sedimentary environment of the study region (Yeh and Hsu 2004; Yeh et al. 2010, 2012; Li et al. 2019). Furthermore, since Late Miocene, the sedimentary layers have been suffered from NW compressional forces. A series of faults, mud diapirs, anticline, and other structures favoring gas hydrate formation developed (Yao et al. 2008). Meanwhile, the increased supply of terrestrial debris resulted in a rapid sediment replenishment and accumulation in this region (Zhang et al. 2002).

\section{DATA AND METHODS}

\subsection{Acquisition}

Four high-resolution MCS lines (SOY, SO1E, T19B, and T19C) close to the LRTPB are acquired via three seismic cruises for this study (Fig. 1b). Line SOY in NE-SW direction and Line SO1E in NW-SE direction were collected aboard the R/V SHIYAN-2 in 2012 and 2014, respectively. Line T19B and T19C in NW-SE direction were collected aboard the ship HAIDIAO-6 in 2016. The detailed acquisition parameters of these lines are listed in Table 1. High-resolution seismic data were acquired using GI air-guns with a dominant frequency of $\sim 80 \mathrm{~Hz}$. The record length is only $6 \mathrm{~s}$ because of the limited source energy from two GI guns.

\subsection{Processing}

To obtain high-resolution seismic profiles, a representative processing flow was applied as follows: demultiplexing, geometry definition, band-pass filter (3-5-120-125 Hz), trace edit, spherical divergence correction, common depth point (CDP) sorting, velocity analysis, normal moveout (NMO) correction, stacking, poststack migration in $\mathrm{f}-\mathrm{x}$ domain, and f-k filter.

Multiples are the primary noise in contaminating the seismic lines. A parabolic Radon transform filtering with inner mute and a surface-related multiple elimination (SRME) were applied to suppress the multiples (Fig. 2). For SO1E (Fig. 2a), multiples were suppressed substantially after using parabolic Radon transform filtering and SRME (Figs. 2b, c). For SOY (Fig. 2d), neither parabolic Radon transform filtering nor SRME can suppress the multiples completely (Figs. 2e, f). However, the parabolic Radon transform filtering method was selected as it works better than the SRME method.

\subsection{AVO Analysis}

Amplitude variation with offset (AVO) analysis is a seismic technique for lithology and oil-gas identification by using the amplitude information of the seismic data (Dondurur 2018). It is based on the Zoeppritz equations which describe the variation of reflection amplitude with incident angle (Ostrander 1984). In this study, the Shuey's simplification of Zoeppritz equations was adopted:

$R(\theta) \approx P+G \sin ^{2} \theta ; \theta \leq 30^{\circ}$

where $R(\theta)$ is the reflection coefficient, $P$ is the intercept (the vertical incident reflection coefficient of $P$ wave), $G$ is the gradient [the rate of change of $R(\theta)$ with incident angle], and $\theta$ is the incident angle (Shuey 1985).

There are five main processing steps for AVO analysis. First, stacking velocities are picked from the velocity spectrum every $50 \mathrm{CDP}$ gathers, and converted into interval velocities using Dix Equation (Dix 1955). Second, a smoothed velocity field is interpolated from the interval velocity field corresponding to the location of CDP gathers. Third, CDP gathers are sorted according to the different offset ranges. Fourth, extract the most suitable wavelet by repeatedly adjusting parameters, such as wavelength, amplitude from three stack sections that obtained by the stack of near-offset, medium-offset, and far-offset CDP gathers. Finally, the $\mathrm{P}$ (intercept), $\mathrm{G}$ (gradient), and $\mathrm{P}+\mathrm{G}$ (the change rate of Poisson's ratio) sections are inverted using the interpolated velocity field and extracted wavelets.

\section{RESULTS}

\subsection{MCS Profiles}

Four processed MCS profiles with their interpretations are presented in Figs. 3 to 6 . The most prominent feature on these profiles are the abnormal reflectors with extremely strong reflection. Among them, a large scale psudo-3D abnormal reflector on lines SO1E and SOY are presented in detail. The key stratigraphic interfaces and unconformities have been interpreted and correlated on reflection seismic data from Li et al. (2007) and Liao et al. (2016).

\subsubsection{SO1E}

Line SO1E is on the continental slope with the bathymetry variation of 750 to $2200 \mathrm{~m}$ (Fig. 3a). On the upslope from 0 to $30 \mathrm{~km}$, gullies are extensively developed by eroding the seafloor into steep channels. These gullies behave 
as "V" and "U" shaped, with widths ranging from 850 to $1700 \mathrm{~m}$ and depths ranging from 50 to $150 \mathrm{~m}$ (Fig. 3c). On the downslope from 40 to $65 \mathrm{~km}$, submarine landslides are observed (Figs. 3b, d, blue lines). Most of them might occur before Quaternary, because they do not go through the Quaternary strata. One submarine landslide extends from Pliocene to Late-Miocene (Figs. 3b, d, blue dashed lines). Yeh et al. (2012) believe that the tilted blocks close to the LRTPB were re-activated, affected by Miocene volcanism and the Pliocene Dongsha uplift event. These submarine landslides may be controlled by the re-activated faults (Fig. 3b, red lines). However, this viewpoint may require more solid evidence.

Below the submarine landslide, there is a high-amplitude LSA with $15 \mathrm{~km}$ in length and $350 \mathrm{~ms}$ thickness in TWT, approximately. It has an average dipping angle of $2^{\circ}$ towards to the downslope. This LSA is characterized by a sharp top boundary, complex internal structures and an indistinct bottom boundary (Fig. 3d). Different from the typical reflection feature of the sedimentary layers above, the internal structure of this LSA reveals strong velocity contrast, intermittent internal reflection, and uneven internal layers. Because most of the seismic energy is blocked out by the LSA, the strata beneath the LSA cannot be clearly observed. Besides this LSA, two anomalies with strong reflection are observed on line SO1E (Figs. 3b, d). They are concordant and saucer-shaped anomalies, respectively.

Quaternary sediments are relatively thicker on the downslope than on the upslope, ranging from 50 to $450 \mathrm{~ms}$ thickness in TWT (Fig. 3b). The thicknesses of the Pliocene and Late-Miocene strata are nearly invariable along this line, while the thickness of the Early Miocene strata is gradually thinned towards the end of the line. The LSA is located between the Early and Late Cenozoic strata. The saucer-shaped anomaly is located between the Mesozoic and Cenozoic strata, while the concordant anomaly is located in the Early-Miocene strata.

\subsubsection{SOY}

Line SOY traverse the continental slope with the bathymetry variation of 1200 to $2500 \mathrm{~m}$ (Fig. 4a). Below the Taiwan Canyon, a series of faults in shallow strata may be related to canyon erosion processes. These faults may control the direction of the Taiwan Canyon, as well as its depth and width (Xu et al. 2014; Hui et al. 2019). On the east side of SOY from 60 to $88 \mathrm{~km}$ range, several gullies are developed by eroding the seafloor into steep channels (Zhong et al. 2017). These gullies behave as "U" shaped, with widths ranging from 2200 to $5800 \mathrm{~m}$ and depths ranging from 150 to $350 \mathrm{~m}$ (Fig. 4a).

On Line SOY, a high-amplitude abnormal reflection also exists as the LSA on Line SO1E. However, the length of this anomaly is only $3 \mathrm{~km}$, typically shorter than the one on Line SO1E of $\sim 15-\mathrm{km}$ in length (Figs. 3, 4). By comparing the exact positions, these two reflection anomalies are located at the intersection of two lines. It means that these two highamplitude abnormal reflections are from the same structure.

East of the LSA, there are some minor reflection anomalies. One of them is a strata-concordant anomaly above Early-Miocene sediments at the east end of SOY. Others are emplaced on Mesozoic basement as complexes with various shapes and lengths (Fig. 4b). Beneath these highamplitude abnormal reflections, there are two chaotic zones without horizontal continuous reflections that connect the upper anomalies with deeper strata. These may be the conduit systems of magma assuming the abnormal reflections are the igneous rocks (Fig. 4c).

At the east side of Taiwan Canyon, Quaternary sediments (770 to $1250 \mathrm{~ms}$ thickness in TWT) are relatively thicker than Pliocene sediments $(\sim 220 \mathrm{~ms}$ thickness in TWT). However, at the west side of Taiwan Canyon, the thickness of Quaternary ( $\sim 60 \mathrm{~ms}$ thickness in TWT) is much thinner than the Pliocene sediments (700 to 950 ms thickness in TWT). The thicknesses of the Early-Miocene and

Table 1. Acquisition parameters of the MCS lines in this study

\begin{tabular}{cccc}
\hline MCS Line & SOY & SO1E & T19B, T19C \\
\hline year & 2012 & 2014 & 2019 \\
Channel number & 72 & 120 & 144 \\
Streamer depth (m) & 5 & 5 & 6 \\
Channel interval (m) & 12.5 & 12.5 & 12.5 \\
Shot interval (m) & 25 & 25 & 20 \\
Record length (s) & 6 & 6 & 6 \\
Sampling rate (ms) & 2 & 2 & 2 \\
Minimum offset (m) & 90 & 90 & 100 \\
Air-gun volume (cu-inch) & 210 & 420 & 420 \\
\hline
\end{tabular}


(a)

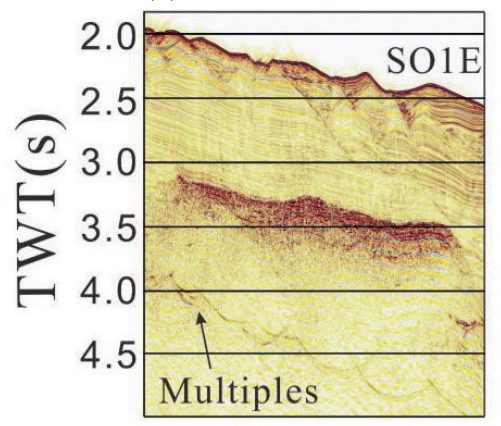

(d)

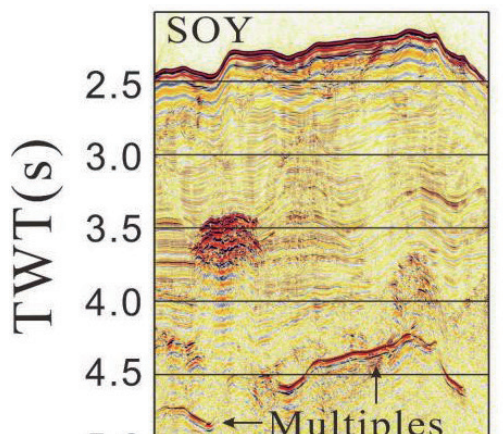

(b)

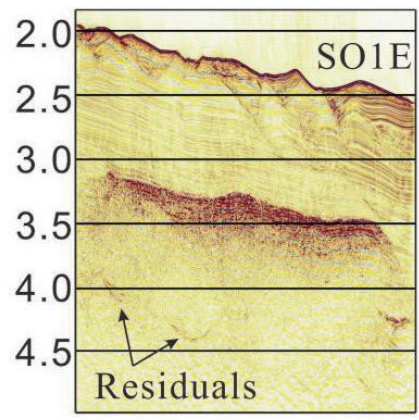

(e)

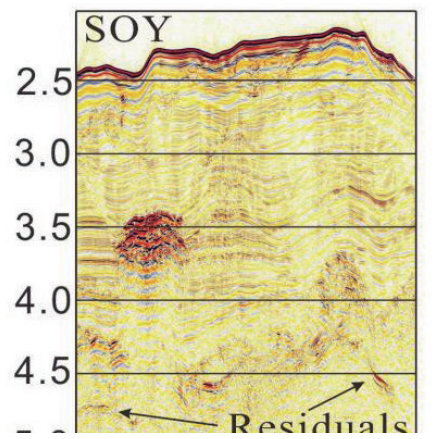

(c)

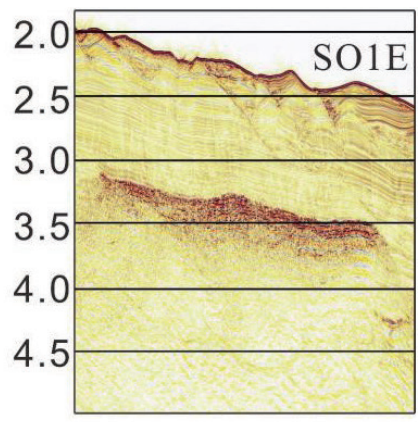

(f)

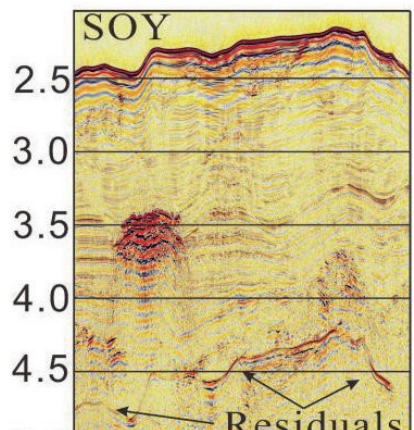

Fig. 2. Examples showing the multiple suppression. (a) and (d) subsections from SO1E and SOY profiles before multiples suppressing. (b) (e) Suppression using parabolic Radon transform filtering with inner mute. (c) (f) Suppression using SRME.
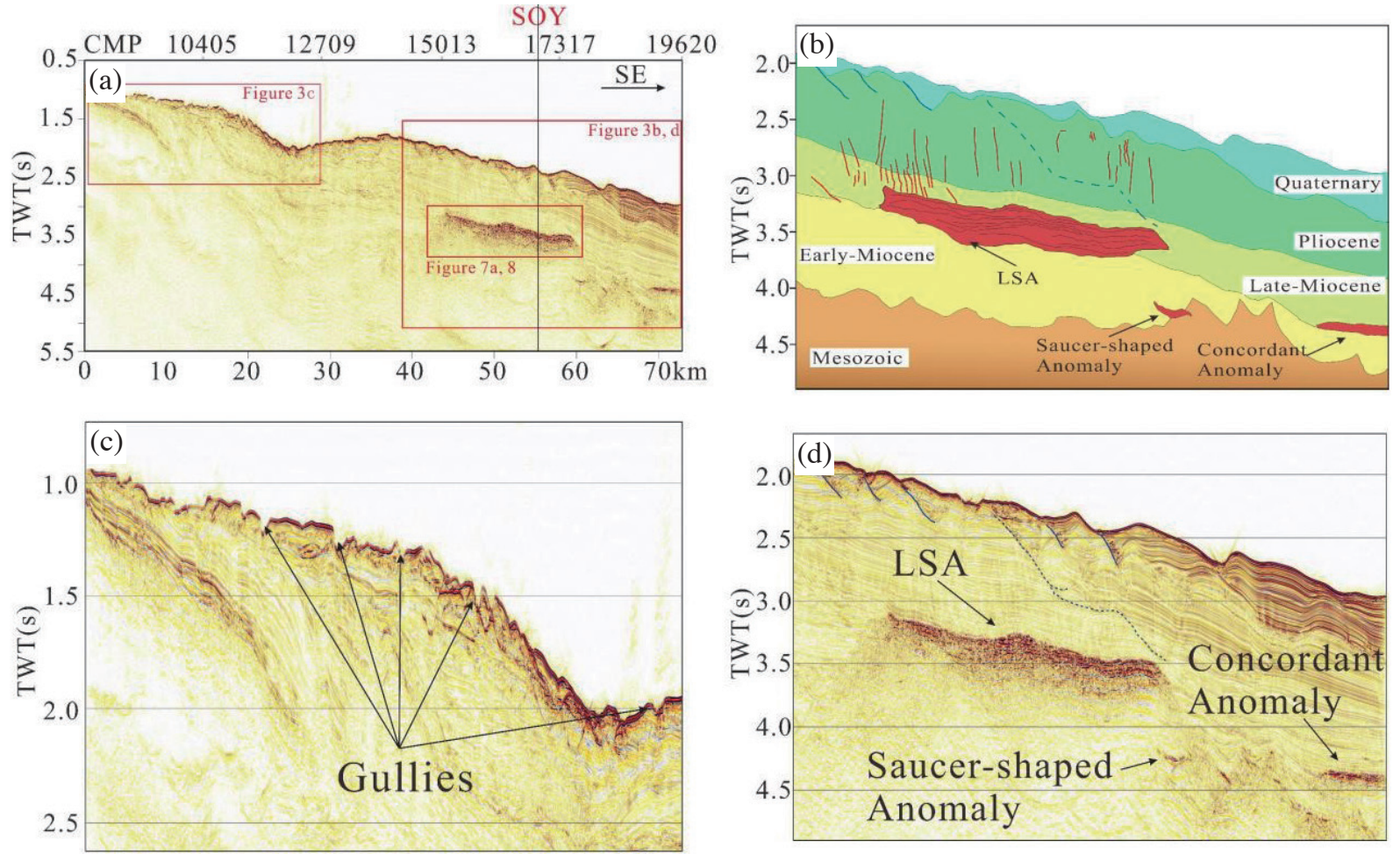

Fig. 3. (a) Seismic profile and (b) its interpretation of Line SO1E. See Fig. 1b for the location of the profile. (c) Close-up of the upslope part. (d) Close-up of the downslope part. TWT: two way travel time. LSA: large-scale Anomaly. 

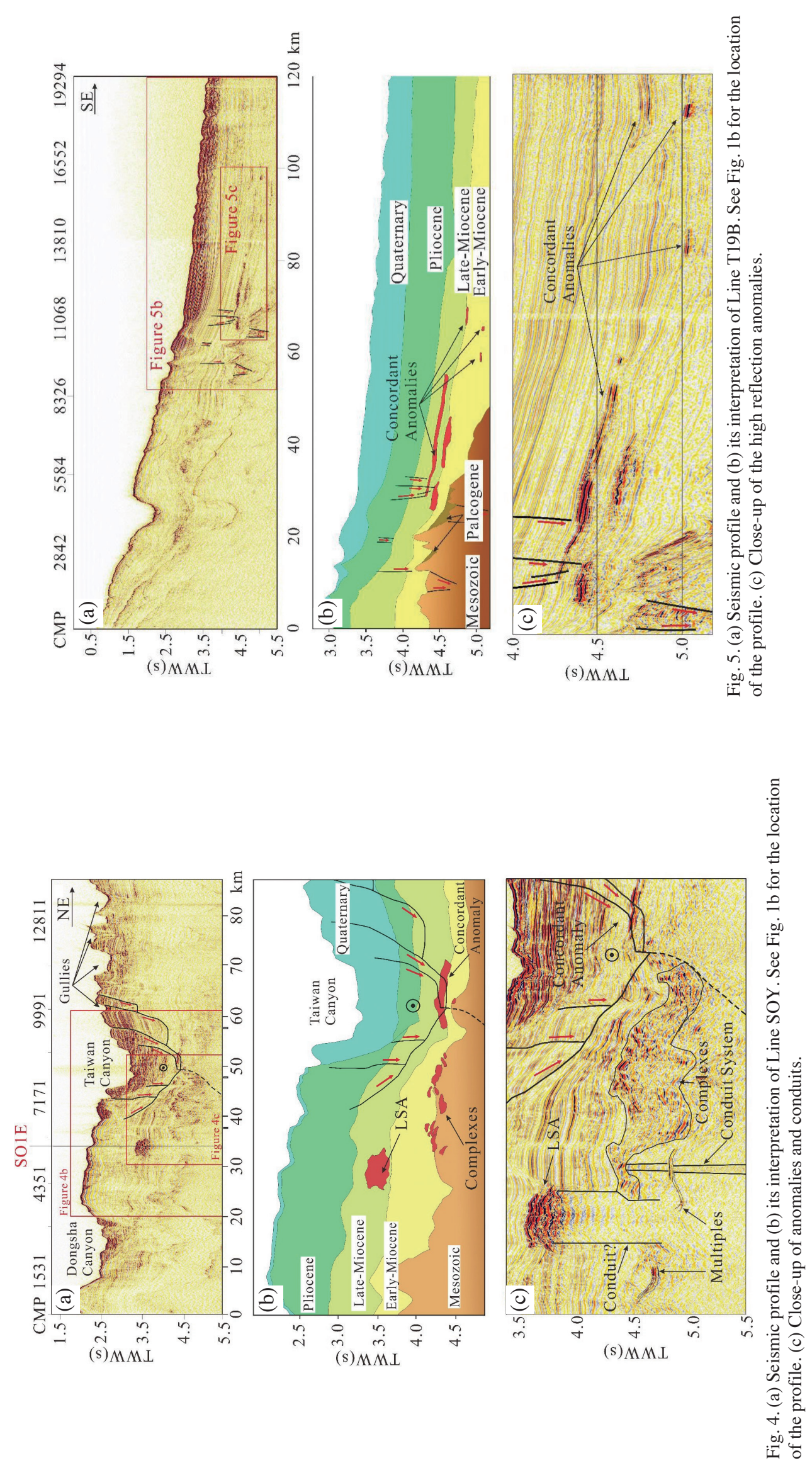

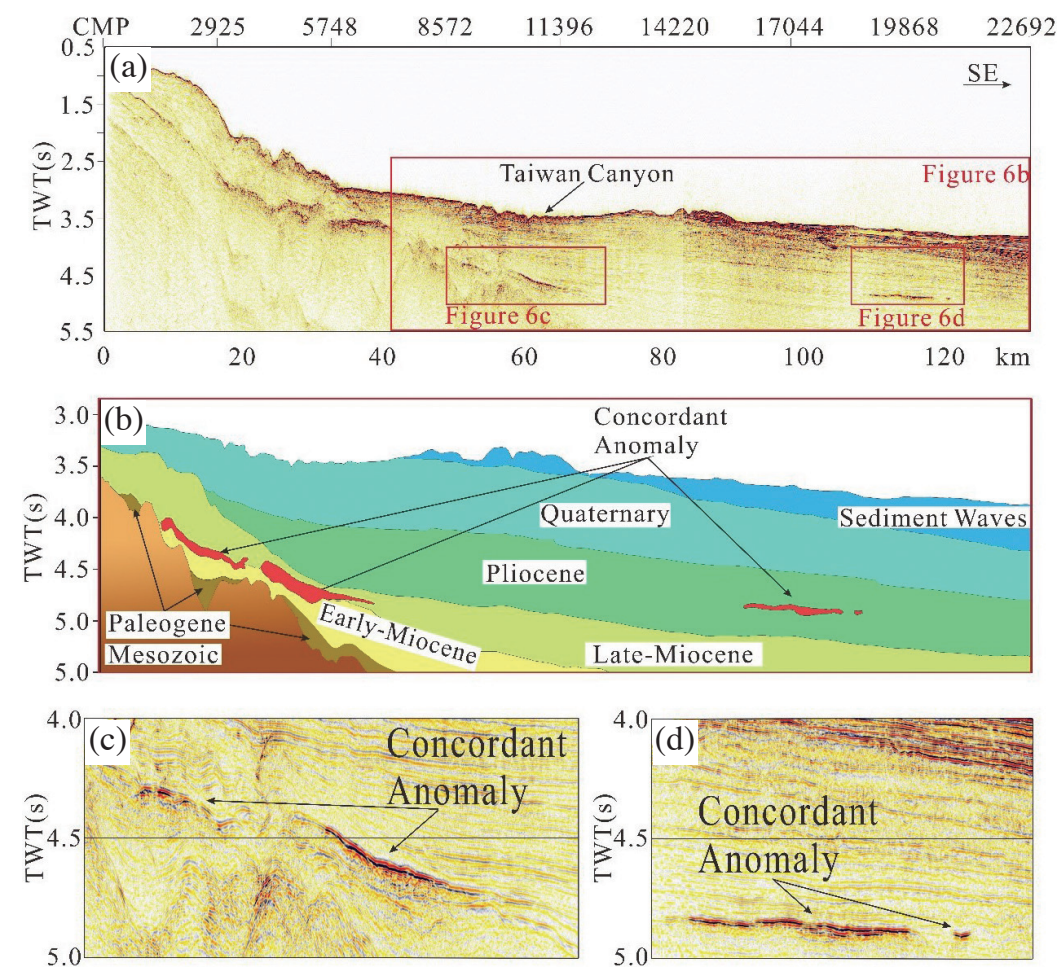

Fig. 6. (a) Seismic profile and (b) its interpretation of Line T19C. See Fig. 1b for the location of the profile. (c) (d) Close-up of the high reflection anomalies.

Late-Miocene strata in the western part of Taiwan Canyon are also slightly greater than the strata thickness in the east.

\subsubsection{T19B and T19C}

Lines T19B and T19C extend from the continental shelf to the bottom of continental slope, with the bathymetry variation of 500 to $3000 \mathrm{~m}$ (Figs. 5a, 6a). On the upslope of Line T19B from 20 to $28 \mathrm{~km}$, there is a very wide " $\mathrm{U}$ " shaped gully with widths of $\sim 8-\mathrm{km}$ and depths of $\sim 440-\mathrm{m}$. On the downslope of Line T19B from 50 to $70 \mathrm{~km}$, a group of faults are observed in Pliocene and Late-Miocene strata or Mesozoic strata. Several strata-concordant anomalies are scattering around the range of $60 \pm 20 \mathrm{~km}$ in Miocene sediments (Figs. 5b, c). Stratigraphic interfaces of Pliocene and Miocene are roughly parallel to the seafloor.

Line T19C goes across the Taiwan Canyon (40 $60 \mathrm{~km}$; Fig. 6). The bathymetry variation decreases rapidly from $800 \mathrm{~m}$ to $2300 \mathrm{~m}$ in the $10-35 \mathrm{~km}$ range of the profile, while it is relatively flat after going into the sea basin. On the southeast of this line $(85-130 \mathrm{~km})$, periodically wavy strata with strong reflection are observed near the seafloor (Fig. 6b). These deepwater sediment waves may be generated by turbidity currents and bottom (contour) currents (Wang et al. 2008; Gong et al. 2012; Bai et al. 2019). Similar to previous lines, several strata-concordant anomalies in Pliocene and Miocene sediments are observed on Line
T19C (Figs. 6b, c, and d). On the eastern of the Taiwan Canyon, the thickness of each strata is more uniform and these stratigraphic interfaces are roughly parallel to the seafloor. Residuals of Paleogene strata (syn-rift strata) can be observed on the Mesozoic strata on Lines T19B and T19C. It can be seen that the reflection anomalies in these two lines and other two lines described above are predominantly distributed in the post-rift strata.

\subsection{Velocity Characteristics of the LSA}

A subsection of Line SO1E is used to create the interval velocity field around the LSA (CDP numbers 14850 - 17851 and time range $1.8-4.2 \mathrm{~s}$, Fig. 7a). From the smoothed velocity (Fig. 7a), it can be seen that the interval velocity rapidly increases from $3200 \mathrm{~m} \mathrm{~s}^{-1}$ to about $4000 \mathrm{~m} \mathrm{~s}^{-1}$ at the LSA with increasing depth. The interval velocity inside the LSA is increased by about $600 \mathrm{~m} \mathrm{~s}^{-1}$ compared to the surrounding strata at the same depth below the seafloor. Beneath the LSA, the interval velocity drops to the same level as the background strata. Such variations can be seen from the velocity analysis of two representative CDP gathers as well. One is outside of the LSA (CDP number 14901) and the other is inside of the LSA (CDP number 16161). Four main constraint points were picked on each of the semblance plot. See Table 2 for their detailed stacking velocities and interval velocities. The synthetic horizontally aligned hyperbolas 

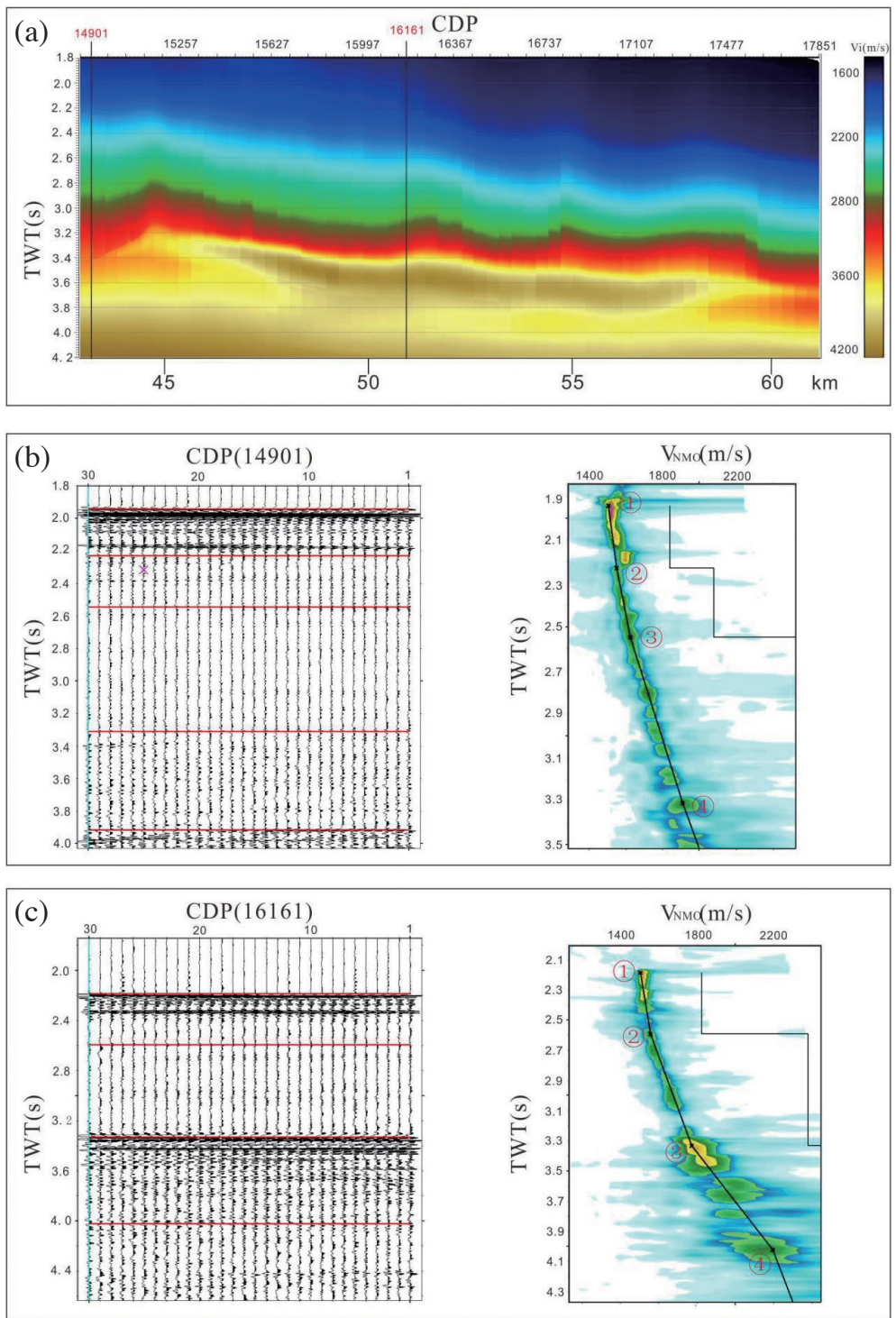

Fig. 7. (a) Interval velocity field between CDPs 14850 - 17851. The vertical lines denote two representative CDP gathers (CDP 14901 outside of the LSA and CDP 16161 inside of the LSA), for velocity analysis. (b) CDP 14901 NMO correction (left) using the velocity picked on the semblance plot (right). (c) Same as (b) but for the CDP 16161.

Table 2. Velocities at CDPs 4901 and 16161 of Line SO1E.

\begin{tabular}{ccccc}
\hline CDP & Points & Time $(\mathbf{m s})$ & Stacking velocity $\left(\mathbf{m ~ s}^{-1}\right)$ & Interval velocity $\left(\mathbf{m ~ s}^{\mathbf{1}}\right)$ \\
\hline \multirow{4}{*}{14901} & 1 & 1939 & 1502 & 1841 \\
& 2 & 2230 & 1549 & 2099 \\
& 3 & 2547 & 1630 & 2579 \\
& 4 & 3318 & 1892 & 3114 \\
\hline \multirow{3}{*}{16161} & 1 & 2177 & 1501 & 1831 \\
& 2 & 2593 & 1556 & 2381 \\
& 3 & 3331 & 1774 & 3591 \\
\hline
\end{tabular}


after NMO correction on the seismic data show the velocities are correctly selected. On the semblance plot outside LSA (Fig. 7b), the semblance contours are arranged along a nearstraight line with gradually increased velocity. In contrast, on the semblance plot inside LSA (Fig. 7c) the semblance contours are changed abruptly after $3.3 \mathrm{~s}$ with a different slope, indicating a sharp velocity contrast and an abrupt velocity increase from the overlying strata to the LSA.

\subsection{AVO Attribute Sections}

After AVO inversion of the subsection of Line SO1E (CDP 14850 - 17851 and time range 1.8 - 4.2 s, Fig. 7a), three AVO attribute sections are obtained, i.e., $P, G$, and $\mathrm{P}+\mathrm{G}$ sections. The $\mathrm{P}$ section shows the $\mathrm{P}$ wave reflection coefficients at zero offset (Shuey 1985), indicating the vertical changes in $\mathrm{P}$ wave impedance (Fig. 8a). The positive reflection coefficients of the uppermost boundary of LSA indicates the $\mathrm{P}$ wave impedance below the uppermost boundary is higher than the $\mathrm{P}$ wave impedance above. According to the equations of $\mathrm{P}$ wave impedance $Z_{P}$ :

$Z_{P}=V_{P} \cdot \rho$

where $V_{P}$ is $\mathrm{P}$ wave velocity, and $\rho$ is density. $\mathrm{P}$ wave impedance is proportional to $V_{P}$ and $\rho$. Based on the discussion above, the higher velocity inside the LSA may be the main reason for the increase of $\mathrm{P}$ wave impedance.

The $\mathrm{G}$ section indicates the change rates (gradients) of reflection coefficients with offset (Shuey 1985) (Fig. 8b). The negative change rates of the uppermost boundary of LSA indicates the $\mathrm{P}$ wave reflection coefficients decrease as offset increase. In general, the variation along the $\mathrm{G}$ section alone is not significant enough for AVO interpretation. Previous studies always combined it with the $\mathrm{P}$ section for interpretation, such as using the $\mathrm{P}+\mathrm{G}$ section.

The $\mathrm{P}+\mathrm{G}$ section shows the change rate of Poisson's ratio (Ostrander 1984) (Fig. 8c). The positive change rate of the uppermost boundary of LSA indicates the Poisson's ratio below the uppermost boundary is higher than that of the overlying sedimentary layer. According to the equations of Poisson's ratio $\sigma$ :

$\sigma=\frac{\left(V_{P} / V_{S}\right)^{2}-2}{2\left(V_{P} / V_{S}\right)^{2}-2}$

where $V_{P}, V_{S}$, are $\mathrm{P}$ and $\mathrm{S}$ wave velocities, respectively. The increase in Poisson's ratio implies an increase in $V_{P} / V_{S}$ of the LSA.

From all the three sections, an interface with opposite polarities in contrast to the uppermost boundary of the LSA is observed on the right side of the LSA between 3.55 -
$3.6 \mathrm{~s}$ (Fig. 8). This opposite variation may indicate that the velocity starts to decrease deeper than this interface. It may be part of the bottom boundary of the laccolith. Because of the shielding effect of the LSA, the lower boundary of the LSA is difficult to determine.

\section{DISCUSSION}

\subsection{Lithology of the LSA}

One of most concerns is the lithology of the LSA. There are three possible origins for the strong reflection anomaly with high seismic velocity, i.e., (1) carbonate sediments; (2) sandstone intrusions; (3) magma intrusion (Xia et al. 2018). Carbonate sediments were always found in $\mathrm{Xi}-$ sha area, Dongsha area and the east of PRMB in northern SCS (Feng 2012; Wu et al. 2014; Li et al. 2015). To our best knowledge, there is no discovery of carbonate sediments in this study area. Although the LSA could be recognized as carbonate platform from the size of the anomaly, this interpretation could be ruled out substantially based on the following aspects. First, the shape feature with bulges at the edges of the anomaly is one of the most typical markers for carbonate platforms recognition (Feng 2012). The LSA has no such bulges at the both ends of the anomaly. Second, carbonate platforms in MCS profiles always have clear bottom boundaries (Wu et al. 2014), while the bottom boundary of LSA is ambiguous. Third, the physical property study of 21 carbonate samples showed that $V_{P} / V_{S}$ of carbonate is about 1.98 (Salah et al. 2020). However, the $V_{P} / V_{S}$ of seafloor sediments is greater than 2.0 and can even reaches to 3.3 (Zhao et al. 2010, 2017; Hou 2019). This means that the Poisson's ratio of the submarine sediment is often greater than that of the carbonate. In contrast, the Poisson's ratio of the LSA is higher than the sedimentary layer above (Fig. 8c). Fourth, carbonate sediments usually form in a shallow-marine environment (Song et al. 2017). The LSA was formed after Late-Miocene, during which was a deep-marine environment after the cessation of seafloor spreading (Taylor and Hayes 1983).

Sandstone intrusions are deep-water sediments that have been intruded into the overlying muddy sediment in an overpressure fluid environment (Wu et al. 2008). AVO attribute is not able to determine whether the LSA is a sandstone intrusion or not, because the acoustic impedance of a sandstone intrusion might be higher or lower than its host strata (Cartwright et al. 2008). However, there are some different aspects between LSA and sandstone intrusions in terms of shape and size. Sandstone intrusions usually behave as "V" or "wing" shaped on MCS profiles with the lateral extent from hundreds of meters to thousands of meters (Yao et al. 2020). Meanwhile, sandstone intrusions generally occur with sand remobilization, which has not been reported along the northern margin of SCS (Sun et al. 2014). 
On the contrary, there are multiple and widespread magmatic activities in the northern margin of SCS after the cessation of seafloor spreading (Zhou et al. 1995; Yan et al. 2001; Wang et al. 2006). These activities are dominated by mafic magmas (Zhang 2014). The Poisson's ratio of igneous rock will be higher than the overlying strata if the rock is mafic-rich or/and the rock is partial melting (Owens and Zandt 1997; Wang et al. 2017). By considering the tectonic background, reflection feature, velocity field, AVO attribute, and forming time of the LSA, we proposed that the LSA is an intrusion of mafic igneous rock.

\subsection{Classification of the Laccolith}

Based on the size and shape of the minor strong reflection anomalies, they can be classified as the intruded sills (Cukur et al. 2010; Schofield et al. 2012; Alves et al. 2015; Xia et al. 2018; Yao et al. 2020) (Figs. 3 - 6). In comparison, the LSA has much wider in size than the minor reflection anomalies.
Laccolith is a kind of intrusive rock that has split two strata, resulting in a domelike structure (Jackson and Pollard 1988; Saint-Blanquat et al. 2006; Horsman et al. 2009). Although the LSA is not a perfect domelike structure, there is still a partially domed structure $\sim 5 \mathrm{~km}$ in length at the center of the LSA. According to Menand (2008), the lateral extent of laccolith ranges from $\sim 1 \mathrm{~km}$ to tens of kilometers, and the thickness ranges from $\sim 500 \mathrm{~m}$ to $1 \mathrm{~km}$ with an aspect ratio up to $\sim 10$. The length and thickness of the LSA is around $15 \mathrm{~km}$ and $1300 \mathrm{~m}$, respectively, and thus the aspect ratio is $\sim 11.5$, assuming interval velocity is $5000 \mathrm{~m} \mathrm{~s}^{-1}$ for the representative igneous rock. In addition, the LSA has similar features as other discovered laccolith with wide top and steep side (Jackson and Pollard 1988; Saint-Blanquat et al. 2006; Horsman et al. 2009).

Furthermore, although the laccolith has different spatial scale and the aspect ratio from the sills, the formation of the laccolith is related to sills (Johnson and Pollard 1973; Menand 2008). With the continuous supply of magma, sill intrudes along the strata, keeping a stable thickness. After
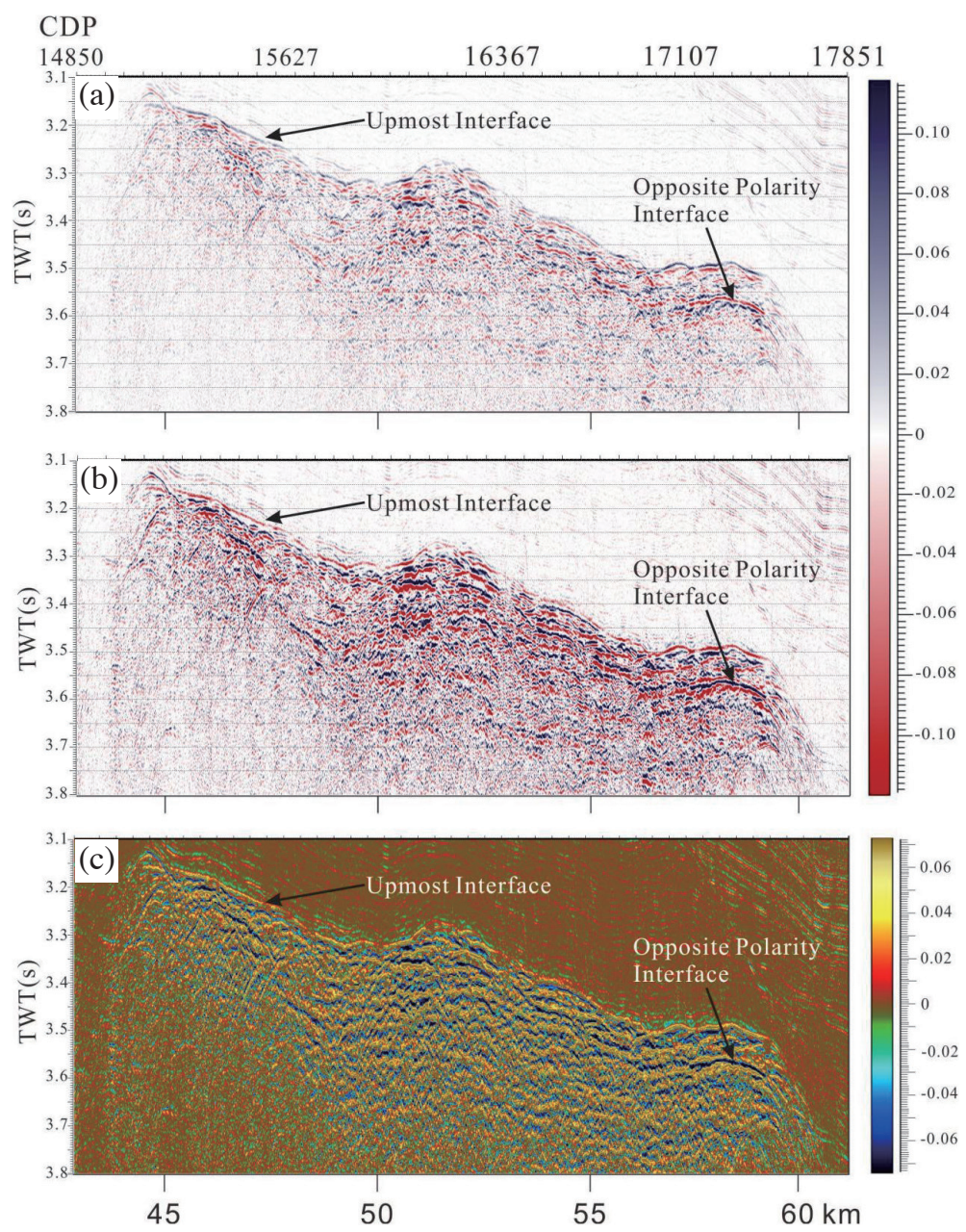

Fig. 8. AVO attribute sections of (a) P, (b) G, and (c) P+G for the LSA. They indicate the P wave reflection coefficients at zero offset, the change rates (gradients) of reflection coefficients with offset, and the change rate of Poisson's ratio, respectively. 
the lateral movement of magma stops, the successive supply of magma makes the intruded layer to be thickened, and thus a transition from sill to laccolith occurs (Johnson and Pollard 1973; Menand 2008). In addition, some studies suggest that a laccolith could be formed during multiple magmatic activities (Horsman et al. 2005, 2009; Morgan et al. 2008). The previous solidified sills can provide a favorable rigidity anisotropy site for the emplacement of the subsequent sills. This mechanism helps sills to thicken vertically to form laccoliths finally (Menand 2008; Agirrezabala 2015). There are multiple magmatic activities in the northern SCS after the cessation of seafloor spreading (Zhou et al. 1995; Yan et al. 2001; Wang et al. 2006). This is might be a favorable condition for the formation of laccolith in the study region.

\subsection{Implications for Magmatism}

In this study, the laccolith is detected at the intersection of Lines SO1E and SOY. Its spatial extents are different on these two lines (Fig. 9). The laccolith on SO1E profile is over $15 \mathrm{~km}$, while it is only $3 \mathrm{~km}$ on SOY profile. This means that the long axis of the laccolith is roughly NW. Such a strike is very close to the NW directional LRTPB near the intersection of Lines SO1E and SOY (Fig. 1). In addition, igneous rocks are mainly distributed on both sides of the LRTPB (Fig. 1b). It indicates that the LRTPB is closely associated with the magma in the northeastern SCS.

Fan et al. (2017) concluded that magma from the mantle plume at the south of Dongsha Island were controlled by faults and dominant orientations of seamounts parallel to the faults (NE and NEE orientation) along the COT (Fig. 1). Decompression melting occurred under the continental slope after the cessation of seafloor spreading (Liu et al. 2021). These magma volumes are not sufficient for large-scale intrusion into the crustal zone (Gao et al. 2015). Based on the scale of the magmatism in the northeastern SCS, it is more likely that these magmas were formed by decompression melting. The NW directional LRTPB might be responsible for the migration of the magma in this study region. Laccolith usually forms in multiple magmatic activities, indicating that the LRTPB may also be re-activated in multiple phases. This view is consistent with Yeh et al. (2012), who mentioned that tilted blocks close to the LRTPB were re-activated during Dongsha Movement.

Most of our discovered magma intrusions are located north of the northern boundary of COT. It probably means that the north boundary of the COT could be further north, in considering that the exact location of COT is still debatable (Zhu et al. 2012; Gao et al. 2016; Larsen et al. 2018; Liu et al. 2018; Yang et al. 2018; Ding et al. 2020). According to the characteristics of magma activities, a schematics of magma activities are presented (Fig. 10). In the LRTPB,

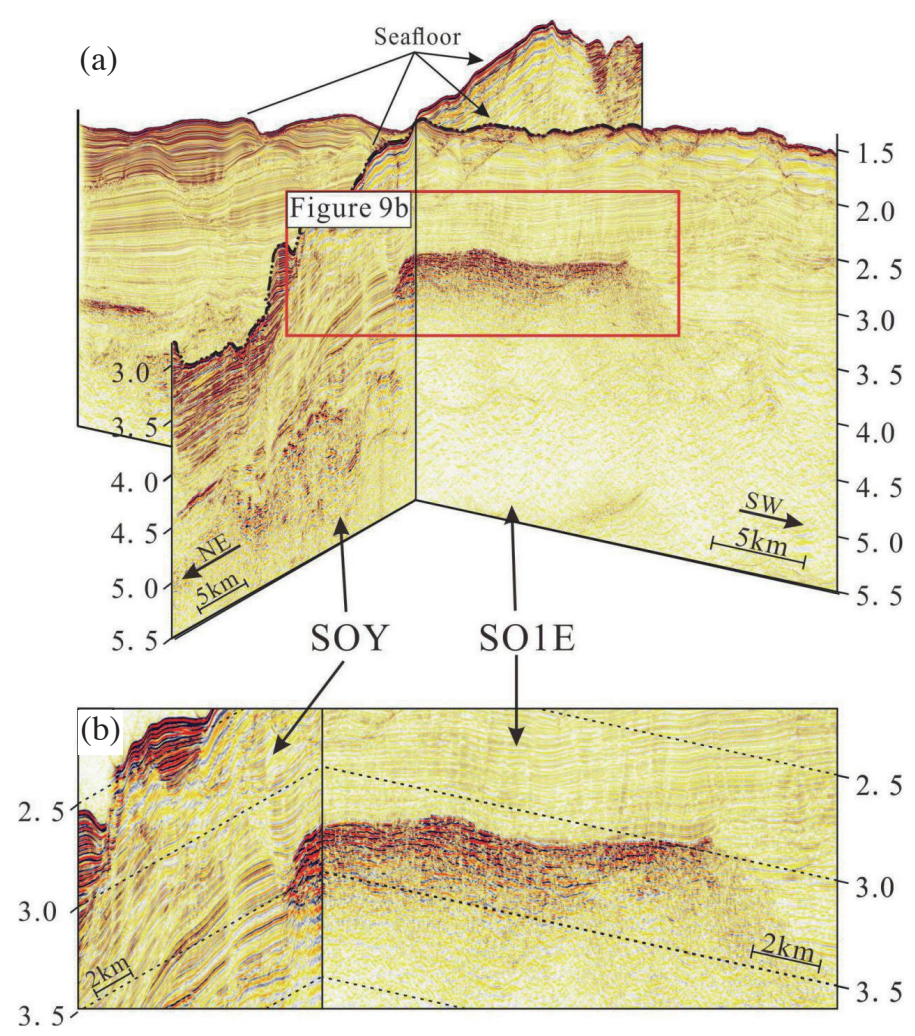

Fig. 9. (a) The Laccolith is imaged in two intersecting seismic profiles, and (b) the detailed view of the red box in (a). The length of the laccolith on SO1E profile is significantly longer than the length on SOY profile. 


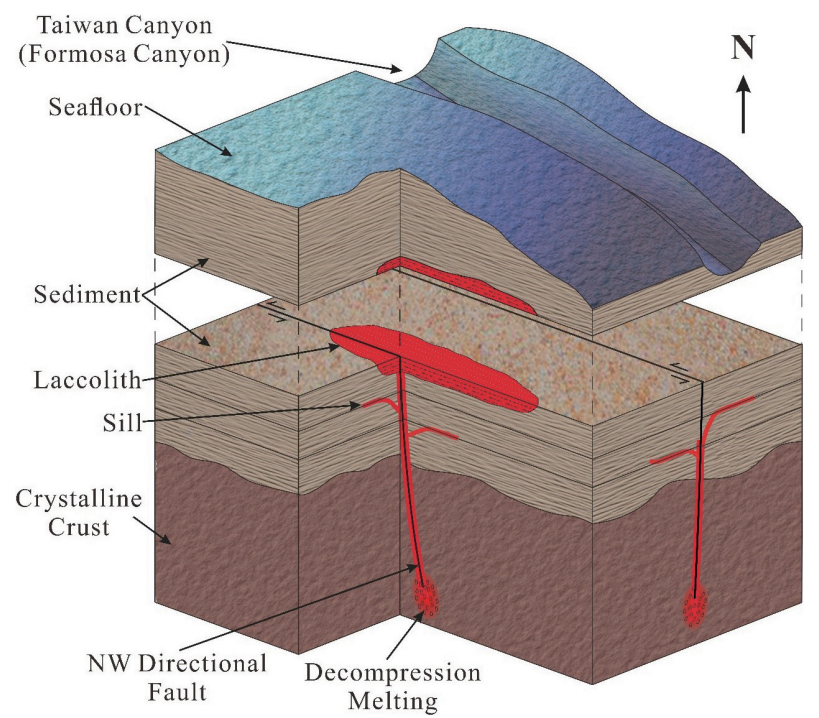

Fig. 10. Schematic showing the fault-induced decompression melting close to the LRTPB. Faults serve as the main conduits for the upward migration of the magma forming sills and laccolith.

magmas ascending from the decompression melting zone along fault zone. The faults controlled magma does not have enough momentum to ascend through the sediment. Under the occurrence multiple magmatic activities, magma intruded into sediment and accumulated to form sills and laccolith along the NW directional LRTPB (Fig. 10).

\section{CONCLUSIONS}

Four high-resolution MCS profiles are processed to reveal the detailed geological structure and magma intrusions in the northeastern SCS. The main points of this study are concluded as follows based on the seismic imaging and AVO analysis:

(1) High-amplitude reflection anomalies are observed from 4 MSC profiles SO1E, SOY, T19B, and T19C. The most prominent one is on SO1E and SOY profiles with a clear upper boundary and ambiguous bottom boundary named as LSA. The spatial size reaches to $\sim 15$ and $\sim 3 \mathrm{~km}$ along and perpendicular to the strike direction, respectively, and $1300 \mathrm{~m}$ in thickness.

(2) The results of velocity field and AVO analyses show that the LSA has a higher P wave velocity and Poisson's ratio than the host strata above.

(3) By comparing the spatial size, shape, velocity feature and AVO attribute with other possible high-amplitude anomalies, we suggest that the LSA on SO1E and SOY profiles is characterized an igneous rock and further classified as a laccolith

(4) The discovery of laccolith and other igneous anomalies indicate that there are still pervasive magmatic activities close to the LRTPB, indicating the magmatic activities is further north than the COT zone. The NW directional LRTPB may be responsible for the migration of the magma.

Acknowledgements We thank the R/V SHIYAN2 and ship HAIDIAO-6 crew for the data acquisition. This study was supported by the Key Special Project for Introduced Talents Team of Southern Marine Science and Engineering Guangdong Laboratory (Guangzhou) (GML2019ZD0104), the Youth Innovation Promotion Association, CAS (Y202076), the Rising Star Foundation of the South China Sea Institute of Oceanology (NHXX2019DZ0101), Special Support Program for Cultivating High-level Talents in Guangdong Province (2019BT02H594), and National Natural Science Foundation of China (Grants U1901217, 91855101, 41876052).

\section{REFERENCES}

Agirrezabala, L. M., 2015: Syndepositional forced folding and related fluid plumbing above a magmatic laccolith: Insights from outcrop (Lower Cretaceous, BasqueCantabrian Basin, western Pyrenees). Geol. Soc. Am. Bull., 127, 982-1000, doi: 10.1130/b31192.1. [Link]

Alves, T. M., K. Omosanya, and P. Gowling, 2015: Volume rendering of enigmatic high-amplitude anomalies in southeast Brazil: A workflow to distinguish lithologic features from fluid accumulations. Interpretation, $\mathbf{3}$, A1-A14, doi: 10.1190/int-2014-0106.1. [Link]

Bai, C., G. Zhang, J. Lu, J. Liang, Z. Yang, W. Yan, D. Zhu, and Y. Tian, 2019: Deep-water sediment waves as a special gas hydrate reservoirs in the Northeastern South China Sea. Mar. Pet. Geol., 101, 476-485, doi: 10.1016/j.marpetgeo.2018.12.031. [Link]

Bautista, B. C., M. L. P. Bautista, K. Oike, F. T. Wu, and R. 
S. Punongbayan, 2001: A new insight on the geometry of subducting slabs in northern Luzon, Philippines. Tectonophysics, 339, 279-310, doi: 10.1016/s00401951(01)00120-2. [Link]

Cartwright, J., D. James, M. Huuse, W. Vetel, and A. Hurst, 2008: The geometry and emplacement of conical sandstone intrusions. J. Struct. Geol., 30, 854-867, doi: 10.1016/j.jsg.2008.03.012. [Link]

Chen, H., X. Wu, D. Zhou, W. Wang, and H. Hao, 2005: Meso-cenozoic faults in Zhujiang River Mouth Basin and their geodynamic background. J. Trop. Oceanogr., 24, 52-61. (in Chinese with English abstract)

Clift, P., G. H. Lee, N. Anh Duc, U. Barckhausen, H. Van Long, and S. Zhen, 2008: Seismic reflection evidence for a Dangerous Grounds miniplate: No extrusion origin for the South China Sea. Tectonics, 27, doi: 10.1029/2007tc002216. [Link]

Cukur, D., S. Horozal, D. C. Kim, G. H. Lee, H. C. Han, and M. H. Kang, 2010: The distribution and characteristics of the igneous complexes in the northern East China Sea Shelf Basin and their implications for hydrocarbon potential. Mar. Geophys. Res., 31, 299-313, doi: 10.1007/s11001-010-9112-y. [Link]

Ding, W., Z. Sun, G. Mohn, M. Nirrengarten, J. Tugend, G. Manatschal, and J. Li, 2020: Lateral evolution of the rift-to-drift transition in the South China Sea: Evidence from multi-channel seismic data and IODP Expeditions $367 \& 368$ drilling results. Earth Planet. Sci. Lett., 531, 115932, doi: 10.1016/j.epsl.2019.115932. [Link]

Dix, C. H., 1955: Seismic Velocities from Surface Measurements. Geophysics, 20,68-86, doi: 10.1190/1.1438126. [Link]

Dondurur, D., 2018: Acquisition and Processing of Marine Seismic Data, Elsevier, 606 pp, doi: 10.1016/C2016-001591-7. [Link]

Fan, C., S. Xia, F. Zhao, J. Sun, J. Cao, H. Xu, and K. Wan, 2017: New insights into the magmatism in the northern margin of the South China Sea: Spatial features and volume of intraplate seamounts. Geochem. Geophys. Geosyst., 18, 2216-2239, doi: 10.1002/2016gc006792. [Link]

Feng, Q., 2012: Reef-flat Reservoir prediction on Zhujiang formation of Dongsha uplifting located in Zhujiangkou Basin. Ph.D. Thesis, China University of Geosciences, China, 158 pp. (in Chinese with English abstract)

Franke, D., 2013: Rifting, lithosphere breakup and volcanism: Comparison of magma-poor and volcanic rifted margins. Mar. Pet. Geol., 43, 63-87, doi: 10.1016/j. marpetgeo.2012.11.003. [Link]

Gao, J., S. Wu, K. McIntosh, L. Mi, B. Yao, Z. Chen, and L. Jia, 2015: The continent-ocean transition at the midnorthern margin of the South China Sea. Tectonophysics, 654, 1-19, doi: 10.1016/j.tecto.2015.03.003. [Link]

Gao, J., S. Wu, K. McIntosh, L. Mi, Z. Liu, and G. Spen- ce, 2016: Crustal structure and extension mode in the northwestern margin of the South China Sea. Geochem. Geophys. Geosyst., 17, 2143-2167, doi: 10.1002/2016gc006247. [Link]

Geoffroy, L., 2005: Volcanic passive margins. C. R. Geosci., 337, 1395-1408, doi: 10.1016/j.crte.2005.10.006. [Link]

Gong, C., Y. Wang, X. Peng, W. Li, Y. Qiu, and S. Xu, 2012: Sediment waves on the South China Sea Slope off southwestern Taiwan: Implications for the intrusion of the Northern Pacific Deep Water into the South China Sea. Mar. Pet. Geol., 32, 95-109, doi: 10.1016/j. marpetgeo.2011.12.005. [Link]

Horsman, E., B. Tikoff, and S. Morgan, 2005: Emplacement-related fabric and multiple sheets in the Maiden Creek sill, Henry Mountains, Utah, USA. J. Struct. Geol., 27, 1426-1444, doi: 10.1016/j.jsg.2005.03.003. [Link]

Horsman, E., S. Morgan, M. de Saint-Blanquat, G. Habert, A. Nugent, R. A. Hunter, and B. Tikoff, 2009: Emplacement and assembly of shallow intrusions from multiple magma pulses, Henry Mountains, Utah. Earth Environ. Sci.Trans. R. Soc. Edinb., 100, 117-132, doi: 10.1017/s1755691009016089. [Link]

Hou, W., 2019: Crustal S-wave velocity structure across the northeastern South China Sea continental margin. Master Thesis, Zhejiang University, 78 pp. (in Chinese with English abstract)

Hsu, S.-K., Y. Yeh, W.-B. Doo, and C.-H. Tsai, 2004: New Bathymetry and Magnetic Lineations Identifications in the Northernmost South China Sea and their Tectonic Implications. Mar. Geophys. Res., 25, 29-44, doi: 10.1007/s11001-005-0731-7. [Link]

Hui, G., S. Li, L. Guo, I. D. Somerville, P. Wang, and Q. Wang, 2019: Mechanisms of submarine canyon formation on the northern continental slope of the South China Sea. Geol. J., 54, 3389-3403, doi: 10.1002/gj.3346. [Link]

Jackson, M. D. and D. D. Pollard, 1988: The laccolith-stock controversy: New results from the southern Henry Mountains, Utah. Geol. Soc. Am. Bull., 100, 117-139, doi: 10.1130/0016-7606(1988)100<0117:Tlscnr $>2.3$. Co;2. [Link]

Jahn, B.-M., P.-Y. Chen, and T.-P. Yen, 1976: Rb-Sr ages of granitic rocks in southeastern China and their tectonic significance. Geol. Soc. Amer. Bull., 87, 763-776.

Johnson, A.M. and D. D. Pollard, 1973: Mechanics of growth of some laccolithic intrusions in the Henry mountains, Utah, I: Field observations, Gilbert's model, physical properties and flow of the magma. Tectonophysics, 18, 261-309, doi: 10.1016/0040-1951(73)90050-4. [Link]

Larsen, H. C., G. Mohn, M. Nirrengarten, Z. Sun, J. Stock, Z. Jian, A. Klaus, C. A. Alvarez-Zarikian, J. Boaga, S. A. Bowden, A. Briais, Y. Chen, D. Cukur, K. Dadd, W. 
Ding, M. Dorais, E. C. Ferré, F. Ferreira, A. Furusawa, A. Gewecke, J. Hinojosa, T. W. Höfig, K. H. Hsiung, B. Huang, E. Huang, X. L. Huang, S. Jiang, H. Jin, B. G. Johnson, R. M. Kurzawski, C. Lei, B. Li, L. Li, Y. Li, J. Lin, C. Liu, C. Liu, Z. Liu, A. J. Luna, C. Lupi, A. McCarthy, L. Ningthoujam, N. Osono, D. W. Peate, P. Persaud, N. Qiu, C. Robinson, S. Satolli, I. Sauermilch, J. C. Schindlbeck, S. Skinner, S. Straub, X. Su, C. Su, L. Tian, F. M. van der Zwan, S. Wan, H. Wu, R. Xiang, R. Yadav, L. Yi, P. S. Yu, C. Zhang, J. Zhang, Y. Zhang, N. Zhao, G. Zhong, and L. Zhong, 2018: Rapid transition from continental breakup to igneous oceanic crust in the South China Sea. Nat. Geosci., 11, 782-789, doi: 10.1038/s41561-018-0198-1. [Link]

Leloup, P. H., R. Lacassin, P. Tapponnier, U. Schärer, D. Zhong, X. Liu, L. Zhang, S. Ji, and P. T. Trinh, 1995: The Ailao Shan-Red River shear zone (Yunnan, China), Tertiary transform boundary of Indochina. Tectonophysics, 251, 3-84, doi: 10.1016/00401951(95)00070-4. [Link]

Lester, R., H. J. A. Van Avendonk, K. McIntosh, L. Lavier, C.-S. Liu, T. K. Wang, and F. Wu, 2014: Rifting and magmatism in the northeastern South China Sea from wide-angle tomography and seismic reflection imaging. J. Geophys. Res., 119, 2305-2323, doi: 10.1002/2013jb010639. [Link]

Li, C.-F., Z. Zhou, J. Li, H. Hao, J. Geng, 2007: Structures of the northeasternmost South China Sea continental margin and ocean basin: Geophysical constraints and tectonic implications. Mar. Geophys. Res., 28, 59-79, doi: 10.1007/s1 1001-007-9014-9. [Link]

Li, C.-F., Z. Zhou, H. Hao, H. Chen, J. Wang, B. Chen, and J. Wu, 2008: Late Mesozoic tectonic structure and evolution along the present-day northeastern South China Sea continental margin. J. Asian Earth Sci., 31, 546561, doi: 10.1016/j.jseaes.2007.09.004. [Link]

Li, C.-F., J. Li, W. Ding, D. Franke, Y. Yao, H. Shi, X. Pang, Y. Cao, J. Lin, D. K. Kulhanek, T. Williams, R. Bao, A. Briais, E. A. Brown, Y. Chen, P. D. Clift, F. S. Colwell, K. A. Dadd, I. Hernández-Almeida, X.-L. Huang, S. Hyun, T. Jiang, A. A. P. Koppers, Q. Li, C. Liu, Q. Liu, Z. Liu, R. H. Nagai, A. Peleo-Alampay, X. Su, Z. Sun, M. L. G. Tejada, H. S. Trinh, Y.-C. Yeh, C. Zhang, F. Zhang, G.-L. Zhang, and X. Zhao, 2015: Seismic stratigraphy of the central South China Sea basin and implications for neotectonics. J. Geophys. Res., 120, 1377-1399, doi: 10.1002/2014JB011686. [Link]

Li, H., Z. Wu, and M. Xu, 2019: Crustal structure features and origins of high-velocity lower crust in the Northeastern South China Sea. Journal of Marine Sciences, 37, 44-56. (in Chinese with English Abstract)

Liao, W.-Z., A. T. Lin, C.-S. Liu, J.-N. Oung, and Y. Wang, 2016: A study on tectonic and sedimentary development in the rifted northern continental margin of the
South China Sea near Taiwan. Interpretation, 4, SP47SP65, doi: 10.1190/int-2015-0209.1. [Link]

Lin, C., J. Gao, X. Yu, F. Ye, and Y. Tan, 2006: Characteristics of tectonic movement in the northern part of South China Sea during the Cenozoic. Acta Oceanol. Sin., 28, 81-86. (in Chinese with English abstract)

Liu, S., M. Zhao, J.-C. Sibuet, X. Qiu, J. Wu, J. Zhang, C. Chen, Y. Xu, and L. Sun, 2018: Geophysical constraints on the lithospheric structure in the northeastern South China Sea and its implications for the South China Sea geodynamics. Tectonophysics, 742-743, 101-119, doi: 10.1016/j.tecto.2018.06.002. [Link]

Liu, Y., C.-F. Li, Y. Wen, Z. Yao, X. Wan, X. Qiu, J.-Z. Zhang, A. Abbas, X. Peng, and G. Li, 2021: Mantle serpentinization beneath a failed rift and post-spreading magmatism in the northeastern South China Sea margin. Geophys. J. Int., 225, 811-828, doi: 10.1093/ gji/ggab006. [Link]

Lüdmann, T. and H. K. Wong, 1999: Neotectonic regime on the passive continental margin of the northern South China Sea. Tectonophysics, 311, 113-138, doi: 10.1016/s0040-1951(99)00155-9. [Link]

Lüdmann, T., H. K. Wong, and P. Wang, 2001: Plio-Quaternary sedimentation processes and neotectonics of the northern continental margin of the South China Sea. Mar. Geol., 172, 331-358, doi: 10.1016/s00253227(00)00129-8. [Link]

McIntosh, K., L. Lavier, H. van Avendonk, R. Lester, D. Eakin, and C.-S. Liu, 2014: Crustal structure and inferred rifting processes in the northeast South China Sea. Mar. Pet. Geol., 58, 612-626, doi: 10.1016/j.marpetgeo.2014.03.012. [Link]

Menand, T., 2008: The mechanics and dynamics of sills in layered elastic rocks and their implications for the growth of laccoliths and other igneous complexes. Earth Planet. Sci. Lett., 267, 93-99, doi: 10.1016/j. eps1.2007.11.043. [Link]

Morgan, S., A. Stanik, E. Horsman, B. Tikoff, M. de Saint Blanquat, and G. Habert, 2008: Emplacement of multiple magma sheets and wall rock deformation: Trachyte Mesa intrusion, Henry Mountains, Utah. J. Struct. Geol., 30, 491-512, doi: 10.1016/j.jsg.2008.01.005. [Link]

Ostrander, W. J., 1984: Plane-wave reflection coefficients for gas sands at nonnormal angles of incidence. Geophysics, 49, 1637-1648, doi: 10.1190/1.1441571. [Link]

Owens, T. J. and G. Zandt, 1997: Implications of crustal property variations for models of Tibetan plateau evolution. Nature, 387, 37-43, doi: 10.1038/387037a0. [Link]

Saint-Blanquat, M., G. Habert, E. Horsman, S. S. Morgan, B. Tikoff, P. Launeau, and G. Gleizes, 2006: Mechanisms and duration of non-tectonically assisted 
magma emplacement in the upper crust: The Black Mesa pluton, Henry Mountains, Utah. Tectonophysics, 428, 1-31, doi: 10.1016/j.tecto.2006.07.014. [Link]

Salah, M. K., M. Alqudah, and C. David, 2020: Acoustics and petrophysical investigations on upper cretaceous carbonate rocks from northern Lebanon. J. Afr. Earth Sci., 172, 103955, doi: 10.1016/j.jafrearsci.2020.103955. [Link]

Schofield, N., L. Heaton, S. P. Holford, S. G. Archer, C. A.-L. Jackson, and D. W. Jolley, 2012: Seismic imaging of 'broken bridges': Linking seismic to outcropscale investigations of intrusive magma lobes. J. Geol. Soc., 169, 421-426, doi: 10.1144/0016-76492011-150. [Link]

Shuey, R. T., 1985: A simplification of the Zoeppritz Equations. Geophysics, 50, 609-614, doi: 10.1190/1.1441936. [Link]

Sibuet, J.-C., S.-K. Hsu, X. Le Pichon, J.-P. Le Formal, D. Reed, G. Moore, and C.-S. Liu, 2002: East Asia plate tectonics since 15 Ma: Constraints from the Taiwan region. Tectonophysics, 344, 103-134, doi: 10.1016/ s0040-1951(01)00202-5. [Link]

Song, X., C.-F. Li, Y. Yao, and H. Shi, 2017: Magmatism in the evolution of the South China Sea: Geophysical characterization. Mar. Geol., 394, 4-15, doi: 10.1016/j. margeo.2017.07.021. [Link]

Sun, Q., S. Wu, J. Cartwright, S. Wang, Y. Lu, D. Chen, and D. Dong, 2014: Neogene igneous intrusions in the northern South China Sea: Evidence from high-resolution three dimensional seismic data. Mar. Pet. Geol., 54, 83-95, doi: 10.1016/j.marpetgeo.2014.02.014. [Link]

Sun, Z., J. Lin, N. Qiu, Z. Jian, P. Wang, X. Pang, J. Zheng, and B. Zhu, 2019: The role of magmatism in the thinning and breakup of the South China Sea continental margin. National Science Review, 6, 871-876, doi: 10.1093/nsr/nwz116. [Link]

Tapponnier, P., G. Peltzer, A. Y. Le Dain, R. Armijo, and P. Cobbold, 1982: Propagating extrusion tectonics in Asia: New insights from simple experiments with plasticine. Geology, 10, 611-616, doi: 10.1130/0091-7613(1982)10<611:Petian>2.0.Co;2. [Link]

Taylor, B. and D. E. Hayes, 1983: Origin and history of the South China Sea basin. In: Hayes, D. E. (Ed.), The Tectonic and Geologic Evolution of Southeast Asian Seas and Islands: Part 2, Geophysical Monograph Series, Volume 27, American Geophysical Union, 23-56, doi: 10.1029/GM027p0023. [Link]

Uyeda, S. and A. Miyashiro, 1974: Plate Tectonics and the Japanese Islands: A Synthesis. Geol. Soc. Am .Bull., 85, 1159-1170,doi: 10.1130/0016-7606(1974)85<1159:PT ATJI $>2.0 . C O ; 2$. [Link]

Wan, K., S.Xia, J.Cao, J.Sun, and H.Xu, 2017: Deep seismic structure of the northeastern South China Sea: Origin of a high-velocity layer in the lower crust. J. Geophys. Res., 122, 2831-2858, doi: 10.1002/2016JB013481. [Link]

Wang, H., Y. Wang, Y. Qiu, X. Peng, and Q. Huang, 2008: Development and its tectonic activity's origin of turbidity cyrrent sediment wave in Manila Trench, the South China Sea. Acta Sedimentologica Sinica, 26, 3945. (in Chinese with English abstract)

Wang, T. K., M.-K. Chen, C.-S. Lee, and K. Xia, 2006: Seismic imaging of the transitional crust across the northeastern margin of the South China Sea. Tectonophysics, 412, 237-254, doi: 10.1016/j.tecto.2005.10.039. [Link]

Wang, W., J. Wu, L. Fang, G. Lai, and Y. Cai, 2017: Crustal thickness and Poisson's ratio in southwest China based on data from dense seismic arrays. J. Geophys. Res., 122, 7219-7235, doi: 10.1002/2017jb013978. [Link]

Wu, S., Y. Sun, Q. Sun, D. Dong, S. Yuan, and Y. Ma, 2008: Seismic identification and formation mechanism of large-scale sandstone intrusions in deep-water basin. Advances in Earth Science, 23, 562-569. (in Chinese with English abstract)

Wu, S., Z. Yang, D. Wang, F. Lü, T. Lüdmann, C. Fulthorpe, and B. Wang, 2014: Architecture, development and geological control of the Xisha carbonate platforms, northwestern South China Sea. Mar. Geol., 350, 7183, doi: 10.1016/j.margeo.2013.12.016. [Link]

Xia, S., F. Zhao, D. Zhao, C. Fan, S. Wu, L. Mi, J. Sun, J. Cao, and K. Wan, 2018: Crustal plumbing system of post-rift magmatism in the northern margin of South China Sea: New insights from integrated seismology. Tectonophysics, 744, 227-238, doi: 10.1016/j. tecto.2018.07.002. [Link]

Xu, S., Y. Wang, X. Peng, H. Zou, Y. Qiu, C. Gong, and H. Zhuo, 2014: Origin of Taiwan Canyon and its effects on deepwater sediment. Sci. China Earth Sci., 57, 2769-2780, doi: 10.1007/s11430-014-4942-0. [Link]

Yan, P., D. Zhou, and Z. Liu, 2001: A crustal structure profile across the northern continental margin of the South China Sea. Tectonophysics, 338, 1-21, doi: 10.1016/ s0040-1951(01)00062-2. [Link]

Yan, P., H. Deng, H. Liu, Z. Zhang, and Y. Jiang, 2006: The temporal and spatial distribution of volcanism in the South China Sea region. J. Asian Earth Sci., 27, 647659, doi: 10.1016/j.jseaes.2005.06.005. [Link]

Yang, L., J. Ren, K. McIntosh, X. Pang, C. Lei, and Y. Zhao, 2018: The structure and evolution of deepwater basins in the distal margin of the northern South China Sea and their implications for the formation of the continental margin. Mar. Pet. Geol., 92, 234-254, doi: 10.1016/j.marpetgeo.2018.02.032. [Link]

Yang, S. and N. Fang, 2015: Geochemical variation of volcanic rocks from the South China Sea and 
neighboring land: Implication for magmatic process and mantle structure. Acta Oceanol. Sin., 34, 112-124, doi: 10.1007/s13131-015-0759-8. [Link]

Yao, B., M. Yang, S. Wu, and H. Wang, 2008: Natural gas hydrate resources in Chinese waters. Geoscience, 22, 333-341. (in Chinese)

Yao, Z., C.-F. Li, G. He, T. Tao, X. Zheng, T. Zhang, X. Tang, and T. Zhao, 2020: Cenozoic sill intrusion in the central and southern East China Sea Shelf Basin. Mar. Pet. Geol., 119, 104465, doi: 10.1016/j.marpetgeo.2020.104465. [Link]

Yeh, Y.-C. and S.-K. Hsu, 2004: Crustal Structures of the Northernmost South China Sea: Seismic Reflection and Gravity Modeling. Mar. Geophys. Res., 25, 45-61, doi: 10.1007/s1 1001-005-0732-6. [Link]

Yeh, Y.-C., J.-C. Sibuet, S.-K. Hsu, and C.-S. Liu, 2010: Tectonic evolution of the Northeastern South China Sea from seismic interpretation. J. Geophys. Res., 115, doi: 10.1029/2009jb006354. [Link]

Yeh, Y.-C., S.-K. Hsu, W.-B. Doo, J.-C. Sibuet, C.-S. Liu, and C.-S. Lee, 2012: Crustal features of the northeastern South China Sea: Insights from seismic and magnetic interpretations. Mar. Geophys. Res., 33, 307-326, doi: 10.1007/s11001-012-9154-4. [Link]

Yi, H., G. Zhong, and J. Ma, 2007: Characteristics and Basin Evolution of Cenozoic Faults in Taixinan Basin. Petroleum Geology, and Experiment, 29, 560-565. (in Chinese)

Zhang, G., Y. Huang, Y. Zhu, and B. Wu, 2002: Prospect of gas hydrates resources in the South China Sea. Marine Geology and Quaternary Geology, 22, 75-81. (in Chinese with English abstract)

Zhang, L., 2014: Distribution of the Mesozoic Boundary in the Northern South China Sea and Prospects for Hydrocarbon Resources, Geological Publishing Press, $367 \mathrm{pp}$.

Zhang, Q., S. Wu, and D. Dong, 2016: Cenozoic magma- tism in the northern continental margin of the South China Sea: Evidence from seismic profiles. Mar. Geophys. Res., 37, 71-94, doi: 10.1007/s11001-016-92663. [Link]

Zhao, M., X. Qiu, S. Xia, H. Xu, P. Wang, T. K. Wang, C.-S. Lee, and K. Xia, 2010: Seismic structure in the northeastern South China Sea: S-wave velocity and Vp/Vs ratios derived from three-component OBS data. Tectonophysics, 480, 183-197, doi: 183-197, 10.1016/j. tecto.2009.10.004. [Link]

Zhao, S., S. Wu, H. Shi, D. Dong, D. Chen, and Y. Wang, 2012: Structures and dynamic mechanism related to the Dongsha movement at the northern margin of South China Sea. Progress in Geophysics, 27, 10081019. (in Chinese)

Zhao, W., X. Zhang, X. Meng, Z. Wu, J. Qi, T. Hao, Y. Zheng, and L. Kai, 2017: S-wave velocity structures and $\mathrm{Vp} / \mathrm{Vs}$ ratios beneath the South Yellow Sea from ocean bottom seismograph data. J. Appl. Geophys., 139, 211-222, doi: 10.1016/j.jappgeo.2017.02.015. [Link]

Zhong, G., J. Liang, Y. Guo, Z. Kuang, P. Su, and L. Lin, 2017: Integrated core-log facies analysis and depositional model of the gas hydrate-bearing sediments in the northeastern continental slope, South China Sea. Mar. Pet. Geol., 86, 1159-1172, doi: 10.1016/j.marpetgeo.2017.07.012. [Link]

Zhou, H., P. Li, and C. Rao, 1995: Geochemistry of cenozoic volcanic rocks in Zhu Jiangkou Basin and its Geodynamic significance. Geochimica, 24, 33-45. (in Chinese with English abstract)

Zhu, J., X. Qiu, H. Xu, W. Zhan, M. Zhao, X. Wei, J. Sun, R. Yang, S. Xia, and H. Huang, 2012: Seismic reflection characteristic and structure unit division of a continent-ocean transition zone in the northern South China Sea. J. Trop. Oceanogr., 31, 28-34. (in Chinese with English abstract) 